\title{
Monomeric and Dimeric Quinoprotein Alcohol Dehydrogenase from Alcohol-grown Pseudomonas BB1
}

\author{
By M. DIJKSTRA, ${ }^{1}$ W. J. J. VAN DEN TWEEL, ${ }^{2}$ J. A. M. DE BONT, ${ }^{2}$ \\ J. FRANK, JZN ${ }^{1}$ AND J. A. DUINE ${ }^{1 *}$ \\ ${ }^{1}$ Laboratory of Biochemistry, Delft University of Technology, Julianalaan 67, 2628 BC Delft, \\ The Netherlands \\ ${ }^{2}$ Department of Microbiology, Agricultural University, Hesselink van Suchtelenweg 4, \\ 6703 CT Wageningen, The Netherlands
}

(Received 25 March 1985; revised 5 August 1985)

\begin{abstract}
Pseudomonas BB1, grown on alcohols, contained a quinoprotein alcohol dehydrogenase, whose substrate specificity was between those of typical methanol dehydrogenases and ethanol dehydrogenases, and which had a higher turnover number and a different amino acid composition. The enzyme occurred in a dimeric as well as in a monomeric form, and the ratio in which the two forms were found depended on the culture conditions. The mechanism of action and the substrate specificity and affinity of the two forms were identical, while the turnover number of the dimer was twice that of the monomer. This indicates that the catalytic activity of the monomer does not change on dimerization. On inactivating alcohol oxidation of whole cells with cyclopropanol, monomeric and dimeric enzyme became fully inactivated. It is tentatively concluded that both forms participate in alcohol oxidation in vivo.
\end{abstract}

\section{INTRODUCTION}

Gram-negative methylotrophic bacteria oxidize methanol by means of a quinoprotein alcohol dehydrogenase (EC 1 1 1.99.8), having PQQ as its prosthetic group (Duine \& Frank, 1981). Most of these dehydrogenases are dimeric enzymes with a molecular weight of about 120000 . However, two reports describe the isolation of a monomeric enzyme (molecular weight about 60000) from methanotrophic bacteria (Patel \& Felix, 1976; Patel et al., 1978). One of these monomeric enzymes was used in mechanistic studies by Mincey et al. (1981) and, surprisingly, the catalytic mechanism proposed was quite different from the one reported by Duine \& Frank (1981) for a dimeric enzyme. Although the mechanism proposed by Mincey et al. (1981) was refuted for the dimeric form (De Beer et al., 1983; Dijkstra et al., 1984), the proposed mechanism might be valid for a monomeric enzyme. Furthermore, a comparative study of monomer and dimer enzyme seemed worthwhile as it could reveal differences which might explain the occurrence of the two enzyme forms.

In first attempts to purify the dye-linked alcohol oxidizing activity of Pseudomonas BB1, two activities appeared to be present. Further chromatographic experiments indicated that one enzyme activity had twice the molecular weight of the other, suggesting that monomeric as well as dimeric enzyme was present. Since the occurrence of both enzyme forms in one organism could provide an ideal opportunity for comparative studies, it was decided to purify and characterize the activities.

\section{METHODS}

Cultivation of the organism. Pseudomonas BBl was grown at $30^{\circ} \mathrm{C}$ on a mineral medium (van den Tweel \& De Bont, 1985) supplemented with methanol, ethanol or 3-butyn-1-ol $(0.2 \%, v / v)$. Cells were harvested in the exponential growth phase $\left(\mathrm{OD}_{660} \quad 1 \cdot 2-1 \cdot 4\right)$, unless indicated otherwise, washed once with $0.05 \mathrm{M}$-potassium

Abbreviation: PQQ (pyrrolo-quinoline quinone), 2,7,9-tricarboxy-1H-pyrrolo(2,3-f)quinoline-4,5-dione. 
phosphate, $\mathrm{pH} 7 \cdot 0$, and stored at $-20^{\circ} \mathrm{C}$. Continuous growth experiments were done at different dilution rates with the same medium (van den Tweel \& De Bont, 1985).

Purification of the alcohol dehydrogenase activities. Frozen cells cultured on methanol ( $1 \mathrm{~g}$ dry weight) were mixed with $40 \mathrm{ml} 0.05 \mathrm{M}$-sodium acetate buffer, $\mathrm{pH} \mathrm{6.0,} \mathrm{and} \mathrm{the} \mathrm{mixture} \mathrm{sonicated} \mathrm{(12} \mathrm{times} \mathrm{for} 15 \mathrm{~s}, 36 \mathrm{~W})$ with a Branson B12 sonifier. The suspension was centrifuged $(20 \mathrm{~min}, 48000 \mathrm{~g})$, yielding the cell extract. The $\mathrm{pH}$ of the extract was lowered to 4.0 with $1 \mathrm{M}-\mathrm{HCl}$ and the precipitate removed by centrifugation. The $\mathrm{pH}$ of the supernatant was brought to 6.0 with $1 \mathrm{M}-\mathrm{NaOH}$. After adding $\left(\mathrm{NH}_{4}\right)_{2} \mathrm{SO}_{4}$ to $55 \%$ saturation, the precipitate was removed by centrifugation $(20 \mathrm{~min}, 48000 \mathrm{~g})$. The $\left(\mathrm{NH}_{4}\right)_{2} \mathrm{SO}_{4}$ concentration was then brought to $80 \%$ and the precipitate collected by centrifugation. The precipitate was dissolved in and dialysed against ( $500 \mathrm{vols}, 12 \mathrm{~h}$ ) $0.02 \mathrm{M}$-sodium acetate, $\mathrm{pH} 6 \cdot 0$. The dialysed solution was applied to a CM-Sephadex C-50 cation exchanger $(20 \times 1.5 \mathrm{~cm})$. The column was washed with portions of $0.02 \mathrm{M}$-sodium acetate, $\mathrm{pH} 6 \cdot 0$, containing increasing concentrations of $\mathrm{NaCl}$. The activity eluted at a concentration of $0.15 \mathrm{M}-\mathrm{NaCl}$. Active fractions were pooled, concentrated by pressure filtration and dialysed against $0 \cdot 1 \mathrm{M}$-potassium phosphate, $\mathrm{pH} 7 \cdot 0$. The dialysed solution was chromatographed on

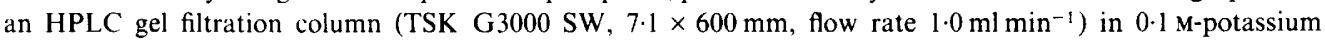
phosphate, $\mathrm{pH} 7 \cdot 0$. The effluent was monitored with a Hewlett-Packard 1040A photodiode array detector.

Enzyme assay. Alcohol dehydrogenase activity was measured in $1.0 \mathrm{ml}$ assay mixtures, $\mathrm{pH} 9 \cdot 0$, containing $64 \mu \mathrm{mol}$ sodium borate, $64 \mu \mathrm{mol} \mathrm{NH}{ }_{4} \mathrm{Cl}, 0 \cdot 1 \mu \mathrm{mol}$ Wurster's blue and $5 \mu \mathrm{mol}$ ethanol. The reaction was started by adding an appropriate amount of enzyme and reaction rates were measured at $22^{\circ} \mathrm{C}$ by following the decrease in absorbance at $600 \mathrm{~nm}$. Wurster's blue was prepared as described by Duine et al. (1978), and a molecular absorption coefficient of $9 \times 10^{3} 1 \mathrm{~mol}^{-1} \mathrm{~cm}^{-1}$ at $600 \mathrm{~nm}$ was used in the calculations (Duine \& Frank, 1980). Kinetic studies were done by varying the substrate concentrations in the assay system. Apparent kinetic parameters were determined from Lineweaver-Burk double reciprocal plots. For the enzyme purification steps, activities were measured with a Clark-type oxygen electrode. Besides enzyme, the assay mixture $(3 \mathrm{ml})$ contained $150 \mu \mathrm{mol}$ Tris/ $\mathrm{HCl}$ buffer, $\mathrm{pH} 9 \cdot 0,0.33 \mu \mathrm{mol}$ phenazine methosulphate and $45 \mu \mathrm{mol} \mathrm{NH}_{4} \mathrm{Cl}$. The reaction was started by adding $15 \mu \mathrm{mol}$ ethanol.

Inactivation experiments with cyclopropanol. A solution of $50 \mu 1$ enzyme (approx. $1 \mathrm{nmol}$ ) in $0.05 \mathrm{M}-\mathrm{NH}_{4} \mathrm{Cl}$, pH 9.0, was oxidized as described by Dijkstra et al. (1984), except that KCN was omitted, in the presence of cyclopropanol. During inactivation, samples were assayed for enzyme activity as described above.

Inactivation experiments with whole cells, harvested in the appropriate growth phase, were done as described by Groeneveld et al. (1984). After the inactivation, the cells were washed twice with 0.05 M-potassium phosphate buffer, $\mathrm{pH} 7 \cdot 0$, and the enzyme forms isolated according to the isolation procedure described above.

Molecular weight determinations. Molecular weights of the native enzymes were determined according to Andrews (1965), using a Sephadex G-200 column $(1 \times 53 \mathrm{~cm})$ equilibrated with $0 \cdot 1 \mathrm{M}$-sodium phosphate, $\mathrm{pH} 6.5$. Marker proteins were bovine pancreas chymotrypsinogen A (molecular weight 25000; Pharmacia), bovine erythrocyte carbonic anhydrase (30000; Boehringer), ox $\beta$-lactoglobulin (40000; Boehringer), bovine serum albumin (67000; Pharmacia), conalbumin (86000; Serva), rabbit muscle $D(-)$-lactate dehydrogenase $(140000$; Boehringer) and yeast alcohol dehydrogenase (150000; Boehringer).

Molecular weights of the subunits were determined on an HPLC gel filtration column (Serva Si 200 Polyol,

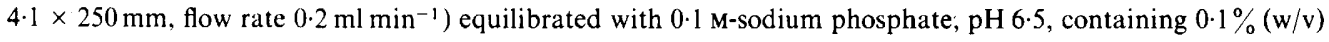
SDS. Proteins (1-2 $\left.\mathrm{mg} \mathrm{ml}^{-1}\right)$ were denatured in the presence of $1 \%(\mathrm{w} / \mathrm{v})$ SDS and $1 \%(\mathrm{v} / \mathrm{v}) \beta$-mercaptoethanol by heating at $100{ }^{\circ} \mathrm{C}$ for $5 \mathrm{~min}$. After centrifugation $(20000 \mathrm{~g}, 5 \mathrm{~min}), 20 \mu \mathrm{l}$ samples were injected and the effluent monitored at $280 \mathrm{~nm}$. Markers (all from Pharmacia) used in these experiments were rabbit muscle phosphorylase $b$ (molecular weight 94000 ), bovine serum albumin (67000), egg white ovalbumin (43000), bovine erythrocyte carbonic anhydrase (30000), soybean trypsin inhibitor (20100) and bovine milk lactalbumin (14400).

$P A G E$. This was done on $76 \mathrm{~mm} 5 \%(\mathrm{w} / \mathrm{v})$ polyacrylamide gel slabs, cross-linked with $0 \cdot 17 \%(\mathrm{w} / \mathrm{v})$ bisacrylamide. The gels were electrophoresed in $36 \mathrm{~mm}$-Tris $/ 39 \mathrm{~mm}$-glycine, $\mathrm{pH} 9 \cdot 0$, or in $36 \mathrm{~mm}$-Tris $/ 21 \mathrm{~mm}$ $\mathrm{H}_{3} \mathrm{PO}_{4}$, pH 6.5, for $1 \mathrm{~h}$ at $300 \mathrm{~V}$ using a Pharmacia GE-411 electrophoresis apparatus, cooled with tap water. Dehydrogenase activity was detected by soaking the gels in $0 \cdot 1 \mathrm{M}$-sodium borate, $0 \cdot 1 \mathrm{M}-\mathrm{NH}_{4} \mathrm{Cl}, 0 \cdot 05 \mathrm{M}$-ethanol, pH 9.0, containing an appropriate amount of Wurster's blue. Protein staining was done with Coomassie brilliant blue R-250.

Analytical methods. Specific absorption coefficients of the enzymes were calculated using the equation derived by Scopes (1974) from absorbance measurements at 205 and $280 \mathrm{~nm}$ : enzymes were chromatographed on the HPLC column used in purification, and spectra were taken by the photodiode-array detector at the top of the eluting enzyme peaks; from this, $A_{280}^{0.1 \%}$ values were obtained. During the purification, protein was determined by the Lowry method with bovine serum albumin as a standard.

Aromatic amino acids in the preparations were estimated by second-derivative spectroscopy on a HewlettPackard Model 8450 A spectrophotometer according to Levine \& Frederici (1982), after denaturing the proteins with guanidine. $\mathrm{HCl}$.

The prosthetic group was analysed as follows. Enzyme solution $(50 \mu \mathrm{l}$; approx. $1 \mathrm{nmol})$ was mixed with $75 \mu \mathrm{l}$ methanol and adjusted to $\mathrm{pH} 2.0$ with $85 \% \mathrm{H}_{3} \mathrm{PO}_{4}$. After centrifugation, the samples were injected onto a $\mathrm{C}_{18}$ 


\section{Table 1. Purification of dye-linked alcohol dehydrogenase from methanol-grown Pseudomonas BBI}

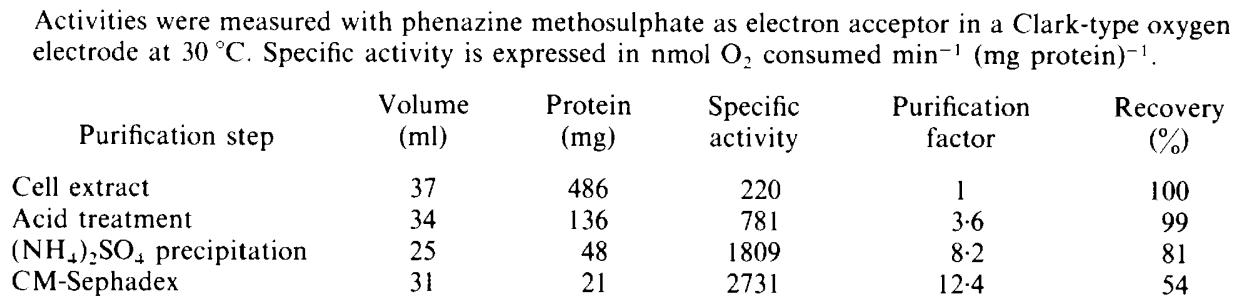

Radial PAK HPLC column as described by Duine et al. (1983), with $85 \% \mathrm{H}_{3} \mathrm{PO}_{4} / \mathrm{H}_{2} \mathrm{O} / \mathrm{methanol} \mathrm{pH} 2 \cdot 0$ $\left(0 \cdot 4: 59 \cdot 6: 40\right.$, by vol.) as the eluent and a flow rate of $1.5 \mathrm{ml} \mathrm{min}^{-1}$. The absorbance at $250 \mathrm{~nm}$ of the effluent was monitored. The column was calibrated with a known amount of PQQ (molar absorption coefficient $\left.18.4 \times 10^{3} 1 \mathrm{~mol}^{-1} \mathrm{~cm}^{-1}\right)$.

ESR measurements were made as described by Duine et al. (1978). Cyclopropanol was prepared as described by Dijkstra et al. (1984).

\section{RESULTS \\ Enzyme purification}

The results of the purification steps are shown in Table 1. As revealed by the chromatogram (Fig. 1), two clearly separated peaks eluted from the gel filtration HPLC column with retention times of 14.5 and $16.6 \mathrm{~min}$. The peaks were collected (fractions I and II, respectively), and both appeared to be active with a specific activity of $35.3 \mu$ mol Wurster's blue reduced $\mathrm{min}^{-1}$ (mg protein $)^{-1}$. Rechromatography of the fractions indicated that they were distinct species which did not interconvert under these chromatographic conditions. Absorption spectra taken upslope, at the top, and downslope of the peaks, were identical. On electrophoresis the fractions showed only one band, by activity as well as by protein staining. The band moved to the anode at $\mathrm{pH} 9.0(10.5 \mathrm{~mm})$ and to the cathode at $\mathrm{pH} 6.5(5.5 \mathrm{~mm})$. Although it is unclear why both fractions showed the same mobility, electrophoresis confirmed that fractions I and II were homogeneous.

\section{Subunit composition}

The different retention times of the fractions on HPLC gel filtration suggested a difference in molecular weight. Gel filtration of fractions I and II on a calibrated Sephadex G-200 column gave molecular weights of $134000 \pm 7000$ and $60000 \pm 3300$ respectively. On the other hand, gel filtration under denaturing conditions gave only one protein peak with a molecular weight of $57000 \pm 4700$ for both fractions. Although this indicated that the enzyme in fraction I consists of two subunits with the same molecular weight as the enzyme in fraction II, the amino acid composition of the subunits might nevertheless be different. Fig. 2 shows that this is very unlikely since the UV-absorption spectra of the fractions are identical, indicating that at least the aromatic amino acid composition of the fractions was identical (Table 2). Also, the similar electrophoretic mobilities of the two fractions indicates that their overall amino acid compositions are similar. It is concluded, therefore, that the dye-linked alcohol dehydrogenase in this organism occurs in a dimeric as well as in a monomeric enzyme form (fractions I and II, respectively). The specific absorption coefficients $\left(A_{280}^{0 \cdot 1 \%}\right)$, calculated as described in Methods, are 2.52 for the dimeric and 2.45 for the monomeric enzyme.

\section{Prosthetic group}

The assay conditions required for activity of the enzyme forms suggested that they belonged to the class of quinoprotein alcohol dehydrogenases. On extraction of the prosthetic group, 2.04 and 0.72 molecules of PQQ per dimer and monomer molecule were found, respectively. In both enzyme forms as they are isolated, PQQ occurs in its free radial form, as indicated by the 


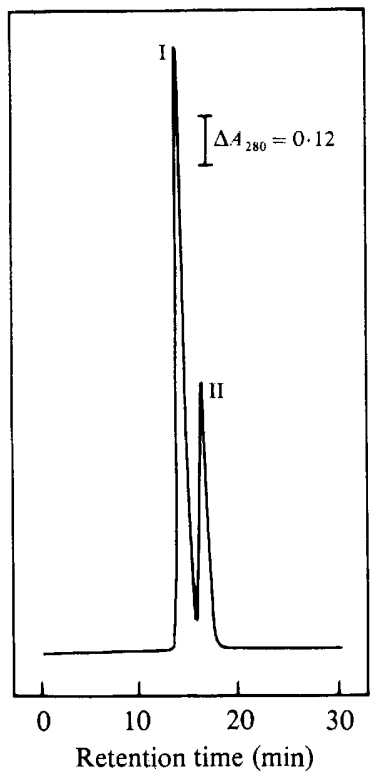

Fig. 1

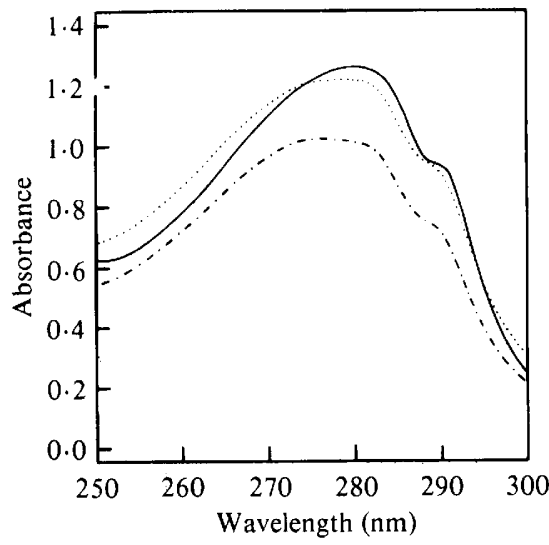

Fig. 2

Fig. 1. Chromatogram of the HPLC gel filtration step, monitored at $280 \mathrm{~nm}$. Monomeric (II) and dimeric (I) enzymes had retention times of 16.6 and $14.5 \mathrm{~min}$, respectively.

Fig. 2. UV-absorption spectra of quinoprotein alcohol dehydrogenases in $0.1 \mathrm{M}$-sodium borate buffer, pH 9.0. The spectra were normalized to a concentration of $0.5 \mathrm{mg}^{2}$ protein $\mathrm{ml}^{-1}$. —, Pseudomonas BB1 enzymes (monomeric and dimeric); -...-, Hyphomicrobium Xenzyme; ....., Pseudomonas aeruginosa enzyme.

\section{Table 2. Aromatic amino acid composition of quinoprotein alcohol dehydrogenases}

Enzymes (1-2 $\mu \mathrm{M})$ were denatured with guanidine. $\mathrm{HCl}$ and analysed by derivative absorption spectroscopy according to Levine \& Federici (1982). The Trp and Tyr concentrations were estimated in the 280-300 nm region, while the Phe concentration was measured in the $245-265 \mathrm{~nm}$ region. In order to compensate for the presence of $\mathrm{PQQ}$, its absorption spectrum was included in the multicomponent analysis procedure. In the calculations, molecular weights of 120000 and 100000 were used for the enzymes from Hyphomicrobium X and Pseudomonas aeruginosa, and 114000 and 57000 for the dimeric and monomeric enzymes from Pseudomonas BB1.

Enzyme source

Pseudomonas BB1 (monomeric) Pseudomonas BB1 (dimeric) Hyphomicrobium X Pseudomonas aeruginosa

\begin{tabular}{|c|c|c|}
\hline \multicolumn{3}{|c|}{$\begin{array}{l}\text { Number of residues per } \\
\text { enzyme molecule }\end{array}$} \\
\hline Phe & Tyr & Trp \\
\hline 17 & 18 & 18 \\
\hline 34 & 36 & 36 \\
\hline 41 & 30 & 34 \\
\hline 27 & 28 & 33 \\
\hline
\end{tabular}

(identical) ESR spectra. In accordance with this, reaction with substrate was only observed after the enzymes were converted into their fully oxidized forms by addition of electron acceptor. However, as revealed by absorption spectra, monomeric enzyme preparations sometimes reached this oxidation state on storage at $4^{\circ} \mathrm{C}$ in the absence of electron acceptor.

\section{Catalytic properties}

The values of the apparent kinetic parameters of the enzyme forms (Table 3) suggest that the subunits in the dimer do not influence each other in so far as the catalytic properties are concerned. This view is supported by the observation that complete inactivation of the dimer 
Table 3. Apparent kinetic parameters of monomeric and dimeric quinoprotein alcohol dehydrogenases from Pseudomonas BBI

Enzyme activity was assayed as described in Methods, using Wurster's blue and various concentrations of substrate. All measurements were corrected for endogenous dye-reduction. Each experiment was done twice

\begin{tabular}{|c|c|c|c|c|}
\hline \multirow[b]{2}{*}{ Substrate } & \multicolumn{2}{|c|}{$\underset{(\mathrm{mM})}{\operatorname{Apparent}} K_{\mathrm{m}}$} & \multicolumn{2}{|c|}{$\begin{array}{c}\text { Apparent } V_{\max } \\
{[\mu \mathrm{mol} \text { substrate oxidized }} \\
\left.\min ^{-1}(\mathrm{mg} \text { protein })^{-1}\right]\end{array}$} \\
\hline & Monomeric & Dimeric & Monomeric & Dimeric \\
\hline \multicolumn{5}{|l|}{ Alcohol } \\
\hline Methanol & $31 \cdot 4$ & $31 \cdot 7$ & $13 \cdot 5$ & $12 \cdot 1$ \\
\hline Ethanol & 0.011 & 0.010 & $20 \cdot 0$ & $15 \cdot 3$ \\
\hline 1-Propanol & $0 \cdot 013$ & 0.008 & $14 \cdot 6$ & $15 \cdot 7$ \\
\hline 2-Propanol & $2 \cdot 6$ & $2 \cdot 7$ & $22 \cdot 1$ & $21 \cdot 8$ \\
\hline \multicolumn{5}{|l|}{ Aldehyde } \\
\hline Formaldehyde & 0.06 & 0.04 & $31 \cdot 5$ & $39 \cdot 1$ \\
\hline Acetaldehyde & $0 \cdot 17$ & $0 \cdot 14$ & $15 \cdot 9$ & $14 \cdot 1$ \\
\hline Propionaldehyde & $1 \cdot 4$ & $1 \cdot 2$ & $25 \cdot 9$ & $24 \cdot 3$ \\
\hline
\end{tabular}

\section{Table 4. Comparison of catalytic activities of quinoprotein alcohol dehydrogenases}

Enzyme activity was assayed as described in Methods, using various concentrations of methanol, except that in the case of enzyme from Hyphomicrobium X the assay mixture contained $10 \mu \mathrm{mol} \mathrm{KCN}$. Molecular weights used in the calculations were as given in Table 2. Each experiment was done twice.

Enzyme source

Pseudomonas BBl (monomeric)

Pseudomonas BB1 (dimeric)

Hyphomicrobium X

Apparent $K_{\mathrm{m}}$
$(\mathrm{mM})$
31.4
31.7
1.6

Turnover
number
$\left(\mathrm{s}^{-1}\right)$
$12 \cdot 9$
$23 \cdot 0$
$0 \cdot 15$

Table 5. Relationship between growth conditions and enzyme form produced

Continuous growth experiments were done, with ethanol as the growth substrate. The ratio of the two enzyme forms was determined by integrating the peaks in the HPLC gel filtration step.

$\begin{array}{cc}\begin{array}{c}\text { Dilution rate } \\ \left(\mathrm{h}^{-1}\right)\end{array} & \begin{array}{c}\text { Ratio of monomeric } \\ \text { to dimeric enzyme }\end{array} \\ 0.01 & 1.1 \\ 0.05 & 2 \cdot 3 \\ 0.09 & 2 \cdot 7 \\ 0.1 & 4.0\end{array}$

enzyme form required 1.7 molecules of cyclopropanol per enzyme molecule. Although this is in agreement with the results for methanol dehydrogenase from Hyphomicrobium X (Dijkstra et al., 1984), comparison of the kinetic properties under identical conditions showed that the enzyme forms of Pseudomonas BB1 have a much higher turnover number (Table 4). In addition, the aromatic amino acid compositions are quite different (Table 2).

\section{Growth conditions and enzyme form}

Experiments with batch-grown cells were not reproducible: no clear-cut relationship could be found between ratio of monomeric to dimeric enzyme and growth phase. On the other hand, continuous growth experiments were reproducible and demonstrated that there is a relationship between the dilution rate and the ratio between the enzyme forms (Table 5). In vivo, both enzyme forms are susceptible to inactivation with cyclopropanol. The purified enzyme forms from cyclopropanol inactivated cells appeared to be fully inhibited and showed absorption spectra identical to those obtained for cyclopropanol inactivated enzyme in vitro (Dijkstra et al., 1984). 


\section{DISCUSSION}

On purification of dye-linked alcohol dehydrogenase from Pseudomonas BB1, two homogeneous fractions were obtained. Comparison of the molecular properties of the enzymes in the fractions revealed that the alcohol dehydrogenase from this organism occurs in a monomeric and a dimeric enzyme form. The enzyme is a quinoprotein and one and two molecules of PQQ were extracted from the monomer and dimer respectively. The substrate specificity resembles that of other quinoprotein alcohol dehydrogenases, lying in between that of methanol dehydrogenase from Hyphomicrobium X (Duine et al., 1978) and ethanol dehydrogenase from Pseudomonas aeruginosa (Groen et al., 1984). This is in accordance with the fact that this organism is able to grow on methanol as well as on ethanol and oxidizes these alcohols only via the quinoprotein alcohol dehydrogenase (Groeneveld et al., 1984). Other dissimilarities are the different amino acid composition (Table 2) and the higher turnover number (Table 4). Mechanistically, however, there is similarity. Both enzyme forms, as isolated, had identical ESR spectra and had to be oxidized before they reacted with substrate. This indicates that the mechanism of the monomeric enzyme is the same as that reported for the dimeric enzyme (Dijkstra et al., 1984).

Quinoprotein alcohol dehydrogenases are mostly dimeric enzymes. Two exceptions have been reported for enzymes from methanotrophic bacteria (Patel \& Felix, 1976; Patel et al., 1978). Growth experiments (Table 5) and the observation that, independent of their concentration, both enzyme forms do not convert into each other, show that monomeric enzyme also occurs in non-methanotrophic bacteria, while both enzyme forms can exist simultaneously in one organism. The comparative studies revealed that the catalytic properties of the subunit are not influenced by the dimerization, as shown by the values of the apparent kinetic parameters (Table 3). On the other hand, the continuous growth experiments indicated that the ratio in which the enzyme forms are synthesized varies. Thus, in view of the absence of kinetic differences, other explanations should be considered. The variable ratio might, for instance, be connected with a change in the architecture of the cytoplasmic membrane and/or the switch to a different branch of the respiratory chain. Otherwise, it could be envisaged that the monomeric enzyme is not functional in alcohol oxidation, but is the precursor of the dimer, the latter probably being located in the periplasm (Alefounder \& Ferguson, 1981). The results of the inactivation experiments on whole cells with cyclopropanol suggest, however, that the latter possibility is unlikely. Both enzyme forms became fully inactivated in the cell, and since inactivation in vitro only occurs with the fully oxidized form (Dijkstra et al., 1984), the implication is that the monomer is somehow coupled to the respiratory chain. Moreover, the observation that equal alcohol oxidation rates are found for cells differing as much as fourfold in ratio of monomer to dimer, also supports the view that the first possibility is more likely. In view of the remaining uncertainties, it would be worthwhile to study the localization and the nature of the primary electron acceptor for both enzyme forms.

We acknowledge Mrs A. Scholten who performed the continuous growth experiments.

\section{REFERENCES}

Alefounder, P. R. \& Ferguson, S. J. (1981). A periplasmic location for methanol dehydrogenase from Paracoccus denitrificans: implications for proton pumping by cytochrome $\mathrm{aa}_{3}$. Biochemical and Biophysical Research Communications 98, 778-784.

ANDREws; P. (1965). The gel-filtration behaviour of proteins related to their molecular weights over a wide range. Biochemical Journal 96, 595-606.

De Beer, R., Duine, J. A., Frank, JzN, J. \& WESTERLING, J. (1983). The role of pyrrolo-quinoline semiquinone forms in the mechanism of action of methanol dehydrogenase. European Journal of Biochemistry 130, 105-109.
Dijkstra, M., Frank, Jzn, J., Jongejan, J. A. \& DUINE, J. A. (1984). Inactivation of quinoprotein alcohol dehydrogenases with cyclopropane-derived suicide substrates. European Journal of Biochemistry 140, 369-373.

Duine, J. A. \& Frank, JR, J. (1980). Studies on methanol dehydrogenase from Hyphomicrobium X. Isolation of an oxidized form of the enzyme. Biochemical Journal 187, 213-219.

Duine, J. A. \& Frank, J. (1981). In Proceedings of the Third International Symposium on Microbial Growth on $C_{1}$-compounds, pp. 21-30. Edited by $\mathrm{H}$. Dalton. London: Heyden $\&$ Son. 
Duine, J. A., Frank, J. \& Westerling, J. (1978). Purification and properties of methanol dehydrogenase from Hyphomicrobium X. Biochimica et biophysica acta 524, 277-287.

Duine, J. A., Frank, JzN, J. \& Jongejan, J. A. (1983). Detection and determination of Pyrroloquinoline Quinone, the coenzyme of quinoproteins. Analytical Biochemistry 133, 239243.

Groen, B., Frank, Jzn, J. \& Duine, J. A. (1984). Quinoprotein alcohol dehydrogenase from ethanolgrown Pseudomonas aeruginosa. Biochemical Journal 223, 921-924.

Groeneveld, A., Dijkstra, M. \& Duine, J. A. (1984). Cyclopropanol in the exploration of bacterial alcohol oxidation. FEMS Microbiology Letters 25, 311-314.

LEVINE, R. L. \& FederiCI, M. M. (1982). Quantitation of aromatic residues in proteins. Model compounds for second-derivative spectroscopy. Biochemistry 21, 2600-2606.

Mincey, T., Bell, J. A., Mildvan, A. S. \& Abeles, R. H. (1981). Mechanism of action of methatoxin- dependent alcohol dehydrogenase. Biochemistry 20, 7502-7509.

Patel, R. N. \& Felix, A. (1976). Microbial oxidation of methane and methanol. Crystallization and properties of methanol dehydrogenase from Methylosinus sporium. Journal of Bacteriology 128, 413-424.

Patel, R. N., Hov, C. T. \& Felix, A. (1978). Microbial oxidation of methane and methanol. Crystallization of methanol dehydrogenase and properties of holo- and apo methanol dehydrogenase from Methylomonas methanica. Journal of Bacterio$\log y$ 133, 641-649.

SCOPES, R. K. (1974). Measurement of protein by spectrophotometry at $205 \mathrm{~nm}$. Analytical Biochemistry 59, 277-282

van Den Tweel, W. J. J. \& De Bont, J. A. M. (1985). Metabolism of 3-butyn-1-ol by Pseudomonas BBI. Journal of General Microbiologi, 131, 3155-3162. 